Article

\title{
Verneite, $\mathrm{Na}_{2} \mathrm{Ca}_{3} \mathrm{Al}_{2} \mathrm{~F}_{14}$, a New Aluminum Fluoride Mineral from Icelandic and Vesuvius Fumaroles
}

\author{
Tonči Balić-Žunić ${ }^{1, * \mathbb{C}}$, Anna Garavelli ${ }^{2}$, ${ }^{\text {, Daniela Pinto }}{ }^{2}$ (D) and Donatella Mitolo ${ }^{3}$ \\ 1 Department of Geosciences and Natural Resource Management, University of Copenhagen, \\ Øster Voldgade 10, DK-1350 København K, Denmark \\ 2 Department of Earth and Geo-environmental Sciences, University of Bari “A. Moro", via E. Orabona 4, \\ I-70125 Bari, Italy; Anna.garavelli@uniba.it (A.G.); Daniela.pinto@uniba.it (D.P.) \\ 3 Autorità di Bacino Distrettuale dell'Appennino Meridionale Sede Puglia, Str. Prov. Per Casamassima km 3, \\ I-70010 Valenzano (BA), Italy; dmitolo@libero.it \\ * Correspondence: toncib@ign.ku.dk; Tel.: +45-35322337
}

Received: 26 October 2018; Accepted: 21 November 2018; Published: 28 November 2018

\begin{abstract}
Verneite, $\mathrm{Na}_{2} \mathrm{Ca}_{3} \mathrm{Al}_{2} \mathrm{~F}_{14}$, is a new mineral first discovered in fumarolic samples from both Hekla, Iceland and Vesuvius, Italy. Additional occurrences are so far from Eldfell and Fimmvörduhals, both on Iceland. Verneite is cubic, $I 2{ }_{1} 3, a=10.264(1) \AA, V=1081.4(3) \AA^{3}, Z=4$, and corresponds to the known synthetic compound. The empirical formula is $\mathrm{Na}_{2.01} \mathrm{Ca}_{2.82} \mathrm{Al}_{2.17} \mathrm{~F}_{14.02}$ (scanning electron microscopy with energy dispersive spectrometer from an unpolished sample). It appears in crystals up to $20 \mu \mathrm{m}$ in diameter, with $\{110\},\{100\}$, and $\{111\}$ as the main forms. In the crystal structure of its synthetic analogue, $\mathrm{Na}$ is coordinated by $7 \mathrm{~F}$ atoms in the form of a capped octahedron, Ca with $8 \mathrm{~F}$ atoms in the form of a bisdisphenoid, and $\mathrm{Al}$ with $6 \mathrm{~F}$ atoms in the form of an octahedron. The crystal structure of $\mathrm{Na}_{2} \mathrm{Ca}_{3} \mathrm{Al}_{2} \mathrm{~F}_{14}$ contains sinuous chains of $\mathrm{Ca}$ coordination polyhedra interlacing with similarly sinuous chains of $\mathrm{Na}$ coordination polyhedra and forming together with them layers parallel to $\{100\}$. The intersecting layers parallel to three equivalent crystallographic planes form a three-dimensional mesh with $\mathrm{Al}$ coordinations imbedded in its holes. The characteristics of $\mathrm{Ca}$ coordinations in fluorides, as well as their relations to other ternary $\mathrm{Na}-\mathrm{Ca}-\mathrm{Al}$ fluorides are discussed. Verneite is named after Jules Verne.
\end{abstract}

Keywords: verneite; new mineral; crystal structure; Hekla; Vesuvius; Eldfell; aluminofluoride

\section{Introduction}

The new mineral verneite, $\mathrm{Na}_{2} \mathrm{Ca}_{3} \mathrm{Al}_{2} \mathrm{~F}_{14}$, was discovered among sublimates collected from fumaroles on the Eldfell and Hekla volcanoes, where a considerable number of new fumarolic minerals has been observed [1]; six of them have so far been fully described [2-7]. The same mineral phase was identified at approximately the same time in a sublimate sample from Vesuvius, belonging to the Pelloux collection, which is stored in the mineralogical section of the Museum of Earth Sciences at Bari University. The original label of this Museum sample, with its 1925 date, indicates "Avogadrite from Vesuvius".

Sveinn P. Jakobsson from the Icelandic Institute of Natural History collected the verneite type specimen on 16 September 1992 on Hekla. He also collected the cotype specimen from the Eldfell volcano in 1988. The holotype and the cotype are kept in the mineral collection of the Icelandic Institute of Natural History, Garðabær, Iceland, under sample numbers NI 15509 and NI 12256, respectively. The mineral was also registered in the samples NI 15518 and NI 17046 from Hekla, and NI 24457 and NI 24565 from Fimmvörduhals, kept in the same museum, and in samples E4-1A, E4-2A and E4-2B, collected on Eldfell in 2009 and presently kept at the Department of Geosciences and Natural Resource 
Management of the University of Copenhagen. The Vesuvius sample is kept in the mineralogical collection of the Department of Earth and Geo-environmental Sciences, University of Bari.

Verneite is named after Jules Verne (1828-1905), the famous French author of novels, poetry, and plays, best known for his adventure novels and his profound influence on the literary genre of science fiction and, through it, the promotion of science, especially among young people. In his novel Voyage au centre de la Terre (1864), Verne describes a group of characters descending through a crater of a quiescent volcano in Iceland (Snæfell) and, after an adventurous journey through exciting Earth's underground, finally being ejected in South Italy with the eruption of a volcano (Stromboli). Therefore, we consider the name verneite appropriate for a mineral found and described by the same team of researchers on the best-known Icelandic and Italian volcanoes. Both the mineral and the mineral name have been approved by the Commission on New Minerals, Nomenclature and Classification of the IMA (no. 2016-112).

In the present work, we give a detailed description of the occurrences of verneite, the morphological and chemical analysis by scanning electron microscopy with energy dispersive spectroscopy (SEM-EDS), and the crystallographic analysis by Powder X-ray Diffraction (PXRD) and discuss its crystal structure details.

\section{Materials and Methods}

The geological settings and a description of the Hekla and Eldfell fumaroles where the new mineral was found are given in the papers mentioned in the Introduction [1-7]. Recently, the mineral has also been identified in samples originating from fumaroles on Fimmvörduhlas, Iceland, active during and after the eruption in 2010 [8]. Verneite occurs in medium to low temperature $\left(170{ }^{\circ} \mathrm{C}\right.$ at the time of sampling) fumaroles, as white-yellowish to brown crusts and massive aggregates up to several $\mathrm{mm}$ in size, sometimes also in transparent, colorless to pale yellowish crystals. In the sample from Eldfell, crystals up to $20 \mu \mathrm{m}$ in diameter with a rhombic dodecahedral habit have been observed (Figure 1a), whereas in the Vesuvius sample, smaller (up to $10 \mu \mathrm{m}$ ) crystals having a combination of $\{100\},\{110\}$, and $\{111\}$ forms have been noted (Figure 1b). Verneite from Vesuvius was found during a reexamination of a sublimate sample belonging to the "Alberto Pelloux mineralogical collection", housed at the "Palace of the Earth Sciences" of Bari University. The original label gives the following indication in Pelloux's own handwriting: "Avogadrite from Vesuvius collected on 15 July 1925-avogadrite or malladrite?" We conclude, therefore, that the mineral originates from fumaroles formed after the violent eruption of 1906, which was the last prior to the date reported in the label. Considering that avogadrite was discovered in 1926 by Professor Ferruccio Zambonini of Naples University, we conclude that the acquisition of the sample (from the well-known mineral salesman "Roberto Palumbo", according to the indication on Pelloux's label) happened after 1926. As indicated on the label, Pelloux himself pointed to a need for further investigation of the sample. This was initially conducted by C.L. Garavelli and coworkers in the 1960s, who reported in it the presence of ralstonite, matteuccite, avogadrite, malladrite, and of a probably new mineral, $\mathrm{MgSiF}_{6} \cdot 6 \mathrm{H}_{2} \mathrm{O}$, suitable for further studies (C.L. Garavelli, unpublished documents). We could not confirm this last phase during the present investigation.

Verneite in Hekla samples forms mixtures with ralstonite and hematite, sometimes also with jakobssonite and "mineral HB" [1] with a still unknown composition, but known PXRD data. The other minerals, which appear together with verneite in the type specimen and other samples from Hekla, are leonardsenite, heklaite, malladrite, opal, and fluorite. In the samples from Eldfell, where the cotype

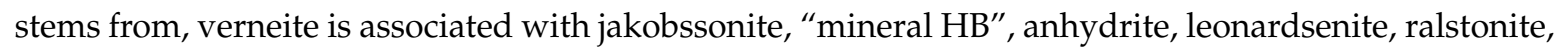
jarosite, and meniaylovite. In the present investigation of the sample from Vesuvius, we found verneite associated with ralstonite and, to a lesser degree, to hieratite and knasibfite.

For the determination of the chemical composition, samples of verneite were analyzed by SEM-EDS. The Eldfell sample was analyzed by a S 360 Cambridge SEM, coupled with an Oxford-Link Ge ISIS EDS equipped with a Super Atmosphere thin window, whereas a 50XVP LEO SEM and 
Oxford AZtec system with an Oxford SDD XMax $\left(80 \mathrm{~mm}^{2}\right)$ detector were used for the Vesuvius sample. The samples were sputtered with a $30 \mathrm{~nm}$ thick carbon film before analysis. As we had to measure inclined surfaces, a "noncritical" working distance was utilized $[9,10]$. X-ray intensities were converted to wt \% values by the ZAF4/FLS quantitative analysis software support of Oxford-Link Analytical. For standards, we used synthetic $\mathrm{LiF}(\mathrm{F})$, albite (Na), wollastonite (Ca), corundum (Al), and orthoclase $(\mathrm{K})$.

The crystallographic data were obtained by PXRD on diffractometers with Bragg-Brentano geometry, first the Panalytical (formerly Philips) PW3710 diffractometer with a long fine focus Cu sealed tube, secondary-beam graphite monochromator, and a variable-slit for the beam divergence. Subsequently, a Bruker-AXS D8 diffractometer with a ceramic Cu tube, primary-beam Ge111 monochromator, fixed divergence slit, and Lynx-Eye silicon strip detector was used. Bruker-AXS program Topas was used for the Rietveld refinement.

The crystallographic data for verneite and other compared crystal structures were calculated by program IVTON [11].

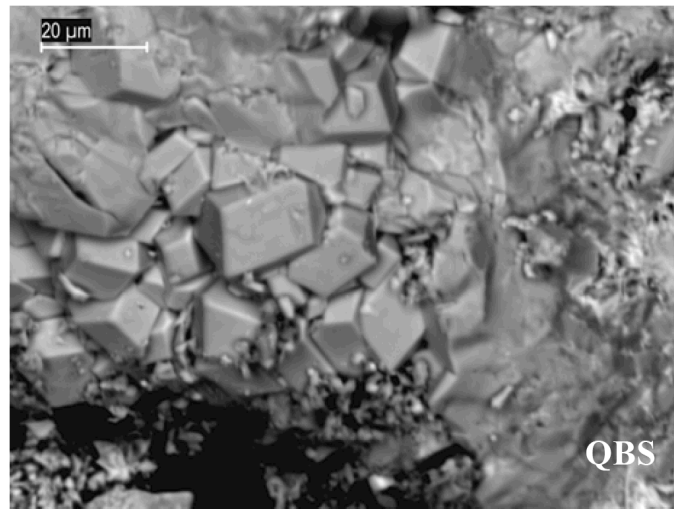

(a)

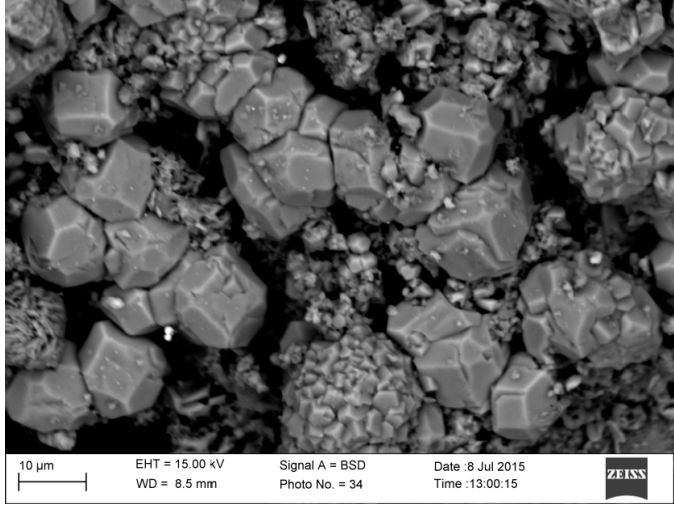

(b)

Figure 1. (a) SEM image of the crystals of verneite in association with fine-grained jakobssonite in the cotype sample from Eldfell. (b) SEM image of verneite crystals from the Vesuvius sample.

\section{Results}

\subsection{Chemical Formula and Physical Properties}

The empirical formulae (based on 7 cations $p f u$ ) are: $\mathrm{Na}_{2.01} \mathrm{Ca}_{2.82} \mathrm{Al}_{2.17} \mathrm{~F}_{14.02}$ for the Eldfell sample and $\left(\mathrm{Na}_{1.47} \mathrm{~K}_{0.09}\right)_{\Sigma 1.56} \mathrm{Ca}_{3.25} \mathrm{Al}_{2.19} \mathrm{~F}_{14.33}$ for the Vesuvius sample. The ideal formula is $\mathrm{Na}_{2} \mathrm{Ca}_{3} \mathrm{Al}_{2} \mathrm{~F}_{14}$, which requires: $\mathrm{F}=54.71, \mathrm{Na}=9.46, \mathrm{Ca}=24.73$, and $\mathrm{Al}=11.10 \mathrm{wt} \%$.

The calculated density of verneite, from the empirical formula and the unit-cell data, is $2.974 \mathrm{~g} / \mathrm{cm}^{3}$. The calculated refractive index using the Gladstone-Dale constants of Mandarino [12] is 1.357.

The cleavage, hardness, streak, and lustre of verneite could not be accurately determined due to the minute size of the crystals and the admixture with other minerals. No fluorescence was observed on the investigated samples, either under short-wavelength or long-wavelength ultraviolet radiation.

It could be expected that verneite is piezoelectric due to its space group symmetry.

\subsection{Crystal Structure Data}

Verneite is analogous to synthetic $\mathrm{Na}_{2} \mathrm{Ca}_{3} \mathrm{Al}_{2} \mathrm{~F}_{14}$ investigated by Courbion and Ferrey [13]. It is cubic, $I 2{ }_{1} 3, a=10.264(1) \AA, V=1081.4(3) \AA^{3}, Z=4$. The atomic parameters and a list of bond lengths and angles are given in Reference [13].

Verneite was identified by PXRD in samples from all localities mentioned above. Rietveld refinements of verneite using the atomic parameters of Courbion and Ferrey [13] match the observed data very well in intensities. Due to this, and the fact that it was impossible to obtain a pure diagram of the mineral, which was always mixed with at least three other components in all the investigated 
samples, a full crystal structure refinement from powder diffraction data, with the inclusion of atomic parameters, was not attempted. Table 1 presents the PXRD data for the sample from the type locality (Hekla), containing verneite, ralstonite, hematite, and jakobssonite, as well as a minor undetermined amount of the still not fully investigated "mineral HB" [1].

Table 1. X-ray powder diffraction data of verneite from Hekla (recorded with automatic variable divergence slit) compared with the experimental diagram of synthetic $\mathrm{Na}_{2} \mathrm{Ca}_{3} \mathrm{Al}_{2} \mathrm{~F}_{14}$ (PDF 36-1496). $\mathrm{HB}=$ mineral $\mathrm{HB}[1] ; \mathrm{R}=$ ralstonite; $\mathrm{J}=$ jakobssonite; $\mathrm{H}$ = hematite .

\begin{tabular}{|c|c|c|c|c|}
\hline hkl/Mineral & $\mathrm{d}(\AA)^{1}$ & $\mathrm{I} / \mathrm{I}_{0} \%{ }^{1}$ & $d(\AA)^{2}$ & $\mathrm{I} / \mathrm{I}_{0} \%^{2}$ \\
\hline 011 & 7.24 & 17.4 & 7.24 & 20 \\
\hline $\mathrm{R}$ & 5.72 & 39.0 & - & - \\
\hline 002 & 5.11 & 17.6 & 5.11 & 14 \\
\hline 211 & 4.18 & 76.2 & 4.18 & 91 \\
\hline$?$ & 3.84 & 15.3 & - & - \\
\hline $\mathrm{H}$ & 3.67 & 25.6 & - & - \\
\hline 022 & 3.62 & 54.7 & 3.62 & 55 \\
\hline $\mathrm{HB}$ & 3.54 & 22.4 & - & - \\
\hline$?$ & 3.30 & 25.6 & - & - \\
\hline 031 & 3.23 & 68.1 & 3.24 & 60 \\
\hline $\mathrm{HB}, \mathrm{J}$ & 3.17 & 28.7 & - & - \\
\hline $\mathrm{R}$ & 2.99 & 56.9 & - & - \\
\hline 222 & 2.95 & 100.0 & 2.96 & 85 \\
\hline $\mathrm{R}$ & 2.87 & 41.6 & - & - \\
\hline 321 & 2.73 & 38.2 & 2.74 & 24 \\
\hline $\mathrm{H}$ & 2.70 & 74.6 & - & - \\
\hline $\mathrm{H}$ & 2.512 & 69.1 & - & - \\
\hline 411 & 2.414 & 40.5 & 2.413 & 33 \\
\hline$?$ & 2.349 & 20.0 & - & - \\
\hline 402 & 2.288 & 40.5 & 2.289 & 21 \\
\hline $\mathrm{H}$ & 2.201 & 35.7 & - & - \\
\hline 332 & 2.184 & 78.3 & 2.183 & 72 \\
\hline $\mathrm{HB}$ & 2.127 & 20.5 & - & - \\
\hline 422 & 2.088 & 20.2 & 2.090 & 5 \\
\hline $\mathrm{R}, \mathrm{J}$ & 2.042 & 22.1 & - & - \\
\hline 341,431 & 2.009 & 98.2 & 2.008 & 100 \\
\hline $\mathrm{R}$ & 1.915 & 37.1 & - & - \\
\hline 251 & 1.871 & 75.1 & 1.877 & 72 \\
\hline $\mathrm{H}$ & 1.840 & 37.9 & - & - \\
\hline 044 & 1.811 & 84.1 & 1.810 & 72 \\
\hline $433+\mathrm{R}$ & 1.755 & 40.5 & 1.756 & 9 \\
\hline 006 & - & - & 1.708 & 7 \\
\hline $\mathrm{H}$ & 1.697 & 51.3 & - & - \\
\hline $\begin{array}{c}611,532 \\
352\end{array}$ & 1.663 & 66.2 & 1.661 & 55 \\
\hline 062 & - & - & 1.620 & 1 \\
\hline $\mathrm{H}$ & 1.607 & 23.0 & - & - \\
\hline 451 & 1.582 & 28.4 & 1.581 & 8 \\
\hline 622 & 1.545 & 45.9 & 1.544 & 38 \\
\hline 361 & 1.512 & 30.6 & 1.510 & 10 \\
\hline
\end{tabular}

Table 2 gives the results of the Rietveld refinement. The refinement shows that the sample is made up by 53(1) wt \% of verneite, 30(1) wt \% of ralstonite, 15.9(6) wt \% of hematite, and 1.6(4) wt \% of jakobssonite, as well as a minor, not determined quantity of "mineral HB". 
Table 2. Rietveld refinement results. "Mineral HB" [1], also present in the sample, was not included in refinement because structural details are unknown. Average crystallite size modelled by Lorentzian function. Global parameters: $R_{\exp }=6.58 \%, R_{w p}=11.6 \%, G o F=1.76$, profile function: Fundamental parameters, background: Chebyshev polynomials.

\begin{tabular}{ccccc}
\hline & Verneite & Ralstonite & Hematite & Jakobssonite \\
\hline average crystallite size $(\mathrm{nm})$ & $121(13)$ & $35(2)$ & $56(5)$ & fixed to 200 \\
$a(\AA)$ & $10.264(1)$ & $9.963(2)$ & $5.035(1)$ & $8.63(3)$ \\
$b(\AA)$ & - & - & - & $6.36(2)$ \\
$c(\AA)$ & - & - & $13.824(4)$ & $7.25(2)$ \\
$\beta\left({ }^{\circ}\right)$ & - & - & - & $114.4(5)$ \\
R-Bragg & fixed $[13]$ & fixed $[14]$ & fixed $[15]$ & fixed $[4]$ \\
atomic parameters & $4.7 \%$ & $6.5 \%$ & $5.8 \%$ & $7.2 \%$ \\
\hline
\end{tabular}

\section{Discussion}

\subsection{Description of the Crystal Structure}

The original description of the crystal structure [13] presents it in an unconventional form as a combination of the cation-centered $\left[\mathrm{AlF}_{6}\right]$ groups (octahedra) and anion-centered $\left[\mathrm{FNaCa}_{3 / 2}\right]_{2}$ framework. This helps in relating the structure to some complex oxide structures presenting it as their "negative" (with the roles of cations and anions in frameworks exchanged), but ignores the coordinations of $\mathrm{Na}$ and $\mathrm{Ca}$ and makes the comparison with other fluorides difficult. Here, we give another view on the crystal structure, based solely on cation coordinations.

As expected from the $\mathrm{Al}: \mathrm{F}$ ratio, verneite is an aluminofluoride with isolated $\left[\mathrm{AlF}_{6}\right]$ octahedral groups and additional $\mathrm{F}$ atoms not bonded to Al. The arrangement of the six $\mathrm{F}$ atoms around the $\mathrm{Al}$ site is almost perfectly octahedral with a perfect sphericity [16] and a volume distortion $(v)$ [17] of only 0.0018 . The $\mathrm{Al}$ atom sits on the three-fold axis $0.036 \AA$ from the centroid of coordination, with eccentricity [16] of 0.0232 . The average Al-F bond distance is $1.804 \AA$ [13].

Ca atoms have an eight-fold coordination in the form of a bisdisphenoid (Figure 2). This type of coordination can achieve a configuration with the minimum ratio of the volume of a circumscribed sphere and the volume of the polyhedron for the coordination number 8 ; in other words, it is a maximum-volume polyhedron for this coordination number [18]. The Ca coordination polyhedron in verneite does not completely fulfill the conditions of a maximum-volume polyhedron because the four $\mathrm{F}$ atoms that form the shortened-disphenoid part of the coordination approach a square-planar arrangement (equatorial atoms on Figure 2). Consequently, its $v$ parameter (or volume distortion compared to the maximum-volume bisdisphenoid) is larger than zero (Table 3). This type of coordination is unique among the $\mathrm{Ca}-\mathrm{F}$ coordinations in mineral fluorides and related synthetic compounds represented in Table 3.

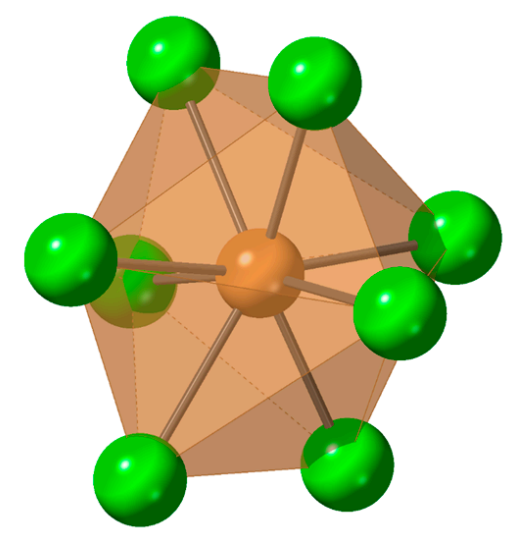

Figure 2. Bisdisphenoidal coordination of $\mathrm{Ca}$ in verneite. Projection based on crystal structure data from Reference [13]. 
Table 3. The coordination parameters of $\left[\mathrm{CaF}_{n}\right]$ coordination polyhedra in fluoride minerals and related synthetic compounds; $v=$ volume distortion; O. = Octahedron; P.b. = Pentagonal bipyramid; S.o. = Split octahedron; Bis. $=$ Bisdisphenoid; S.a. = Square antiprism; C. $=$ Cube; T.t.p. $=$ Tricapped trigonal prism; T.c. $=$ Tricapped cube.

\begin{tabular}{|c|c|c|c|c|c|c|c|c|}
\hline Compound & Site & $\mathrm{CN}$ & $<\mathrm{Ca}-\mathrm{F}>(\AA)$ & $v$ & Asphericity & Eccentricity & Polyhedron & Ref \\
\hline $\mathrm{CaLiAlF}_{6}$ & Ca1 & 6 & 2.281 & 0.0038 & 0 & 0 & $\mathrm{O}$. & [19] \\
\hline $\mathrm{Na}_{4} \mathrm{Ca}_{4} \mathrm{Al}_{7} \mathrm{~F}_{33}$ & Ca1 & 6 & 2.246 & 0.0232 & 0 & 0 & $\mathrm{O}$. & [20] \\
\hline$\beta-\mathrm{NaCaAlF}_{6}$ & $\mathrm{Ca} 1$ & 6 & 2.308 & 0.0439 & 0.0049 & 0.023 & $\mathrm{O}$. & [20] \\
\hline $\mathrm{KCaAl}_{2} \mathrm{~F}_{9}$ & $\begin{array}{l}\mathrm{Ca} 1 \\
\mathrm{Ca} 2\end{array}$ & $\begin{array}{l}6 \\
6\end{array}$ & $\begin{array}{l}2.302 \\
2.292\end{array}$ & $\begin{array}{l}0.0703 \\
0.0559\end{array}$ & $\begin{array}{l}0.0348 \\
0.0426\end{array}$ & $\begin{array}{c}0.0165 \\
0.017\end{array}$ & O. & [21] \\
\hline $\mathrm{CaAlF}_{5}$ & Ca1 & 7 & 2.318 & 0.0265 & 0.0335 & 0.0521 & P.b. & [22] \\
\hline $\mathrm{Ca}_{2} \mathrm{AlF}_{7}$ & $\begin{array}{l}\mathrm{Ca} 1 \\
\mathrm{Ca} 2\end{array}$ & $\begin{array}{l}7 \\
7\end{array}$ & $\begin{array}{l}2.316 \\
2.346\end{array}$ & $\begin{array}{l}0.0344 \\
0.1391\end{array}$ & $\begin{array}{l}0.0217 \\
0.0112\end{array}$ & $\begin{array}{l}0.0248 \\
0.0404\end{array}$ & $\begin{array}{l}\text { P.b. } \\
\text { S.o. }\end{array}$ & [23] \\
\hline$\alpha-\mathrm{NaCaAlF}_{6}$ & $\begin{array}{l}\mathrm{Ca} 1 \\
\mathrm{Ca} 2\end{array}$ & $\begin{array}{l}7 \\
7 \\
\end{array}$ & $\begin{array}{l}2.351 \\
2.343\end{array}$ & $\begin{array}{l}0.0943 \\
0.0869\end{array}$ & $\begin{array}{l}0.0331 \\
0.0405\end{array}$ & $\begin{array}{c}0.054 \\
0.0467\end{array}$ & $\begin{array}{l}\text { transitional } \\
\text { P.b./S.o. }\end{array}$ & [24] \\
\hline $\mathrm{Na}_{2} \mathrm{Ca}_{3} \mathrm{Al}_{2} \mathrm{~F}_{14}$ & Ca1 & 8 & 2.374 & 0.0234 & 0.0254 & 0.0286 & Bis. & [13] \\
\hline $\mathrm{BaCaAlF}_{7}$ & $\begin{array}{l}\mathrm{Ca} 1 \\
\mathrm{Ca} 2 \\
\end{array}$ & $\begin{array}{l}8 \\
8 \\
\end{array}$ & $\begin{array}{l}2.372 \\
2.372 \\
\end{array}$ & $\begin{array}{l}0.0467 \\
0.0569\end{array}$ & $\begin{array}{l}0.0309 \\
0.0271 \\
\end{array}$ & $\begin{array}{l}0.0361 \\
0.0362\end{array}$ & S.a. & [25] \\
\hline $\mathrm{Ba}_{2} \mathrm{CaMgAl}_{2} \mathrm{~F}_{14}$ & $\mathrm{Ca} 1$ & 8 & 2.371 & 0.0565 & 0.0453 & 0.0349 & S.a. & [26] \\
\hline $\mathrm{Ca}_{2} \mathrm{PbAlF}_{9}$ & $\begin{array}{l}\mathrm{Ca} 1 \\
\mathrm{Ca} 2 \\
\end{array}$ & $\begin{array}{l}8 \\
8 \\
\end{array}$ & $\begin{array}{l}2.360 \\
2.361 \\
\end{array}$ & $\begin{array}{c}0.088 \\
0.0899 \\
\end{array}$ & $\begin{array}{l}0.0181 \\
0.0234 \\
\end{array}$ & $\begin{array}{l}0.0237 \\
0.0241 \\
\end{array}$ & $\begin{array}{c}\text { transitional } \\
\text { C./S.a. }\end{array}$ & [27] \\
\hline $\mathrm{CaNa}_{3} \mathrm{Mg}_{3} \mathrm{AlF}_{14}$ & Ca1 & 8 & 2.421 & 0.1136 & 0.0583 & 0 & distorted C. & [28] \\
\hline $\mathrm{CaF}_{2}$ & Ca1 & 8 & 2.365 & 0.1522 & 0 & 0 & C. & [29] \\
\hline $\mathrm{Ca}_{13} \mathrm{Y}_{6} \mathrm{~F}_{43}$ & $\begin{array}{l}\text { Ca3 } \\
\text { Ca1* } \\
\text { Ca2 }\end{array}$ & $\begin{array}{c}8 \\
9 \\
10\end{array}$ & $\begin{array}{l}2.341 \\
2.617 \\
2.491\end{array}$ & $\begin{array}{l}0.1444 \\
0.0296 \\
0.0478\end{array}$ & $\begin{array}{c}0.021 \\
0.0627 \\
0.0407\end{array}$ & $\begin{array}{l}0.0142 \\
0.0628 \\
0.0576\end{array}$ & $\begin{array}{c}\text { distorted C. } \\
\text { T.t.p. } \\
\text { T.c. }\end{array}$ & [30] \\
\hline
\end{tabular}

The crystal structure data for the table are compiled from Reference [31]. As can be seen, the coordination number $(\mathrm{CN})$ of $\mathrm{Ca}$ (coordinated with $\mathrm{F}$ atoms only) varies from 6 to 8 or even, rarely, 9 or 10 . In the crystal structures with $\mathrm{CN} 6$, the coordination is in the form of a nearly perfect octahedron (in colquirite [19]) or subsequently more distorted octahedra in $\mathrm{Na}_{4} \mathrm{Ca}_{4} \mathrm{Al}_{7} \mathrm{~F}_{33}$ [20], $\beta-\mathrm{NaCaAlF}_{6}$ [20], and $\mathrm{KCaAl}_{2} \mathrm{~F}_{9}$ [21]. Ca with $\mathrm{CN7}$ appears in moderately distorted pentagonal bipyramids in jakobssonite [4,22] and $\mathrm{Ca}_{2} \mathrm{AlF}_{7}$ (Ca1) [23]. A regular pentagonal bipyramid is the maximum-volume polyhedron for $\mathrm{CN} 7$ and the $v$ values are calculated in comparison with it. $\mathrm{Ca} 2$ in $\mathrm{Ca}_{2} \mathrm{AlF}_{7}$ and the Ca coordinations in $\alpha-\mathrm{NaCaAlF}_{6}[24]$ have this parameter significantly different from zero because they represent a different type of coordination geometry, close to a "split octahedron", the ideal form of which would have $v=0.1333$ [17]. From values in Table 3, we can see that Ca2 in $\mathrm{Ca}_{2} \mathrm{AlF}_{7}$ closely approaches this form, whereas the coordinations in $\alpha-\mathrm{NaCaAlF}_{6}$ are transitional between a pentagonal bipyramid and a "split octahedron". For CN8, the ideal types of coordination polyhedra are, in addition to bisdisphenoid, the cube (0.1522), the hexagonal bipyramid (0.0462), the square antiprism (0.0351), and the bicapped trigonal prism (0.0733). The numbers in parentheses are the $v$ values in comparison with the maximum-volume bisdisphenoid. The forms observed in Ca fluorides from Table 3 are a regular cube in fluorite and distorted cubes in tveitite (Ca3) [30] and coulsellite [28]. The coordinations in calcioaravaipaite [27] are transitional between the cube and square antiprism, whereas the coordinations in usovite [26] and $\mathrm{BaCaAlF}_{7}[25]$ are moderately distorted square antiprisms. In tveitite, the $\mathrm{CN} 9$ and $\mathrm{CN} 10 \mathrm{Ca}$ sites are also present. Ca1 with a tricapped trigonal prism coordination actually occupies a larger $\mathrm{CN} 12$ icosahedral void and is a split site, whereas the coordination of $\mathrm{Ca} 2$ can be described as a cube where one corner has been substituted by an $\mathrm{F}_{3}$ triangle [30].

$\mathrm{Na}$ atoms have a seven-fold coordination with a capped octahedron as the coordination polyhedron (Figure 3). The capped octahedral face is broader than the opposite one (Figure 3). 
The average Na-F bond distance is $2.431 \AA$ [13], whereas the polyhedron distortion parameters are eccentricity $=0.0043$, asphericity $=0.0615$, and $v=0.0849$ (compared to regular pentagonal bipyramid, which is the maximum-volume polyhedron for CN7). There is a considerably larger number of $\mathrm{Na}$ containing fluorides than those containing $\mathrm{Ca}$, with a larger variability of coordination types; a comparative study of $\mathrm{Na}$ coordinations in fluorides will not be presented here, but in a special following article. We only mention that the Na coordination polyhedron type in verneite seems to be unique compared to other mineral fluorides, similar to the case of the Ca coordination polyhedron.

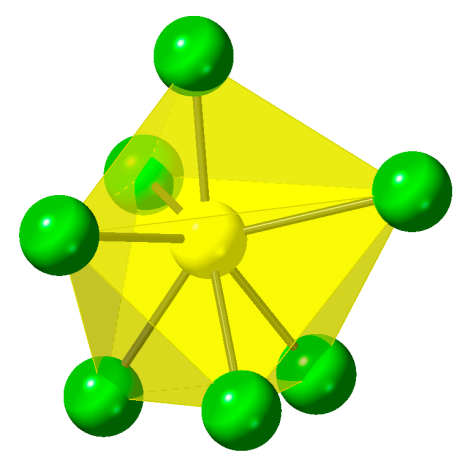

Figure 3. Na coordination in verneite. The three-fold axis is vertical. Projection based on crystal structure data from Reference [13].

The Ca coordination polyhedra build sinuous chains by sharing edges. They are interlaced by the sinuous chains of equally edge-sharing $\mathrm{Na}$ coordination polyhedra, and together these two types of chains build layers parallel to $\{100\}$ (Figure 4). The layers, parallel to the three equivalent crystallographic planes, form a three-dimensional mesh that houses $\mathrm{Al}$ coordination octahedra in its interstices (Figure 5). The $\mathrm{Al}$ coordination octahedra share one face with a $\mathrm{Na}$ coordination polyhedron and three edges with $\mathrm{Ca}$ coordination polyhedra. Three $\mathrm{F}$ atoms at the corners that belong to the shared face are characterized by longer F-Al bonds ( $1.824 \AA$ ) and are each bonded to one $\mathrm{Al}$, one $\mathrm{Ca}$, and two $\mathrm{Na}$. The three $\mathrm{F}$ atoms in the corners of the opposite face with shorter F-Al bonds $(1.784 \AA)$ make bonds to one $\mathrm{Al}$ and two $\mathrm{Ca}$ each. The directions of the sinuous chains of $\mathrm{Ca}$ and Na coordination polyhedra on the adjacent $\{100\}$ faces, e.g., on the (100) and (010) faces, are mutually perpendicular (in this case [010] and [001], respectively), as required by the space group symmetry (Figure 5).

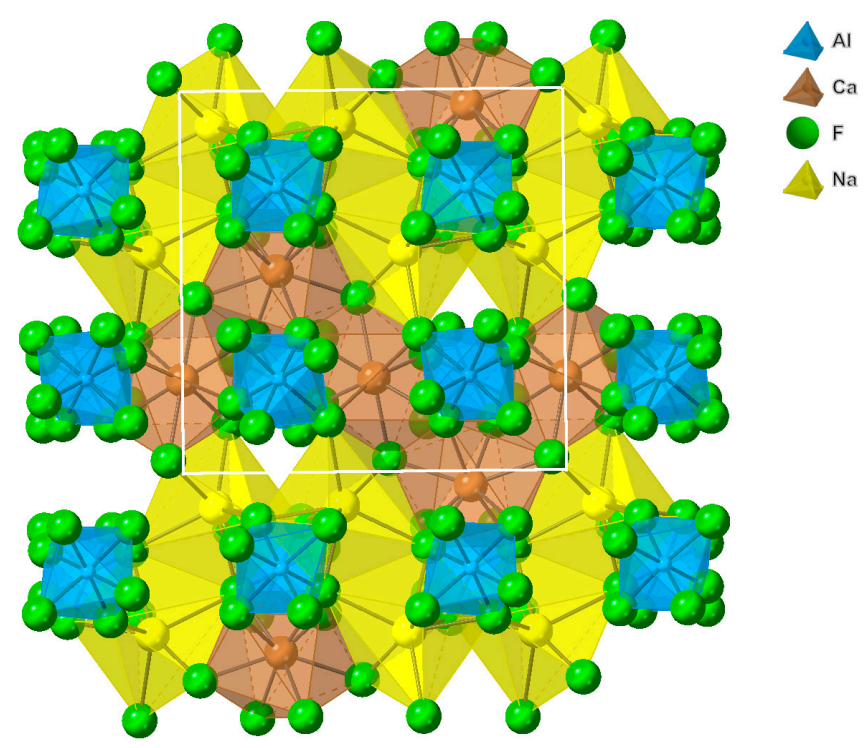

Figure 4. A $\{100\}$ layer from the crystal structure of verneite, formed by sinuous chains of Ca coordinations and Na coordinations, and overlaid/underlain by the $\left[\mathrm{AlF}_{6}\right]$ octahedra. Projection based on crystal structure data from Reference [13]. 


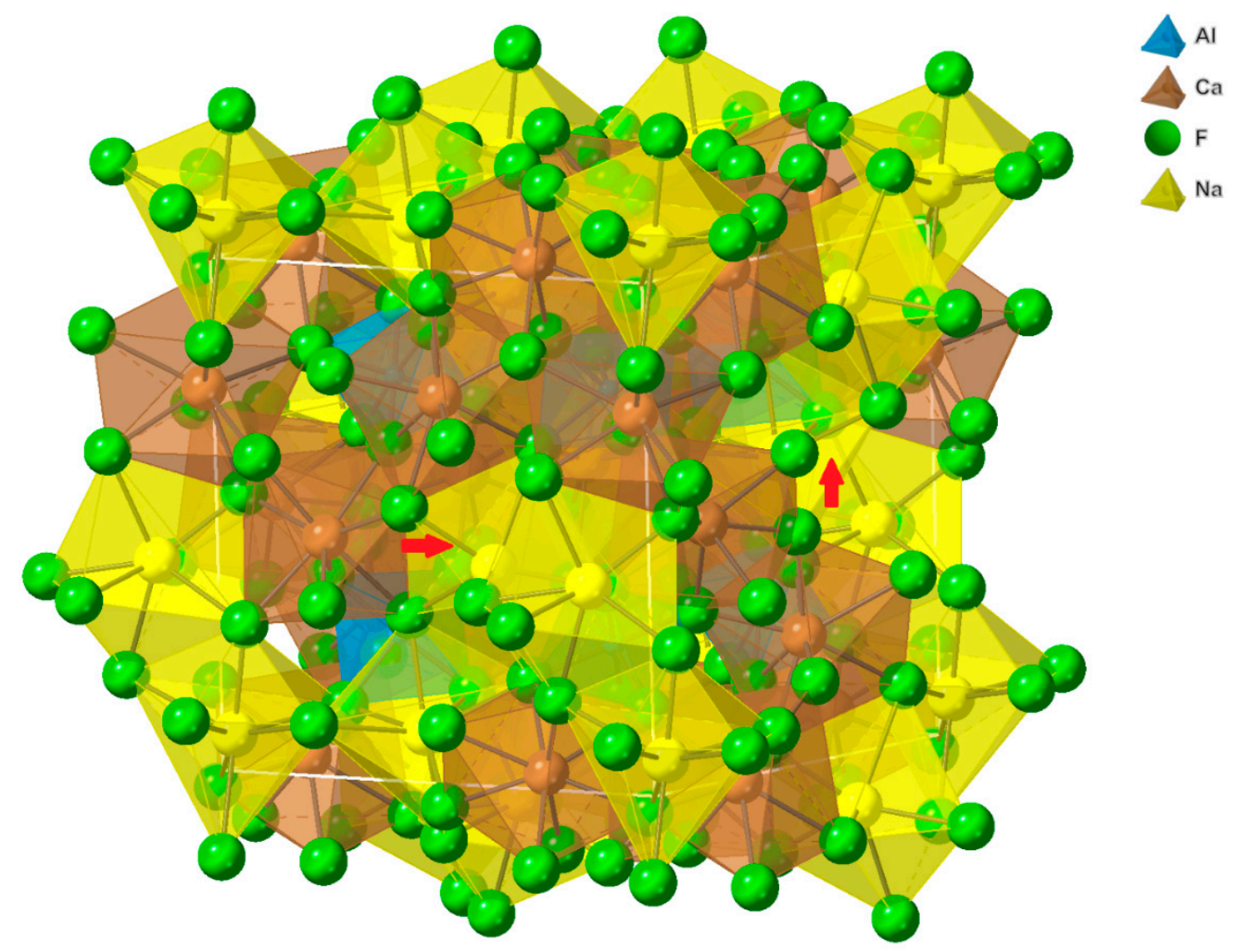

Figure 5. A general direction view of coordination polyhedra in one unit cell of verneite. Red arrows indicate the directions of sinuous chains of coordination polyhedra on the (100) and (010) surfaces of the unit cell. Projection based on crystal structure data from Reference [13].

\section{2. $\mathrm{NaF}-\mathrm{CaF}_{2}-\mathrm{AlF}_{3}$ System and the Natural Occurrences of Phases}

Only three ternary phases have been originally reported in the phase system $\mathrm{NaF}-\mathrm{CaF}_{2}-\mathrm{AlF}_{3}$ [32], the low-temperature form of $\mathrm{NaCaAlF}_{6}$, its high-temperature polymorph, and $\mathrm{NaCaAl}_{2} \mathrm{~F}_{9}$. Later investigations showed that the material investigated by Craig and Brown [32] and reported as the low-temperature form of $\mathrm{NaCaAlF}_{6}$ actually has the composition $\mathrm{Na}_{2} \mathrm{Ca}_{3} \mathrm{Al}_{2} \mathrm{~F}_{14}$ [13]. In addition, the composition of $\mathrm{NaCaAl}_{2} \mathrm{~F}_{9}$ was corrected to the structural formula $\mathrm{Na}_{4} \mathrm{Ca}_{4} \mathrm{Al}_{7} \mathrm{~F}_{33}$ [20]. $\mathrm{NaCaAlF}_{6}$ was confirmed to have a high-temperature (stable above $620^{\circ} \mathrm{C}$ ) and a low-temperature form, based on determinations of their structures $[20,24]$. The crystal structure data for the four confirmed phases in the phase system are represented in Table 4. To the best of our knowledge, none of the phases from this phase system have been observed before in nature, and $\mathrm{Na}_{2} \mathrm{Ca}_{3} \mathrm{Al}_{2} \mathrm{~F}_{14}$ reported here is the first example. The synthetic work showed that this compound is stable up to $719^{\circ} \mathrm{C}$ at atmospheric pressure and decomposes at higher temperatures to a mixture of the high-temperature $\mathrm{NaCaAlF}_{6}$ and fluorite [13]. It forms readily at temperatures lower than $600{ }^{\circ} \mathrm{C}$ in the part of the phase system comprising approximately equal molar amounts of $\mathrm{Na}, \mathrm{Ca}$, and $\mathrm{Al}$, and it crystallizes rather than the low-temperature form of $\mathrm{NaCaAlF}_{6}$, which is metastable and could be synthesized only through hydrothermal synthesis [20]. The fourth ternary phase in this phase system, $\mathrm{Na}_{4} \mathrm{Ca}_{4} \mathrm{Al}_{7} \mathrm{~F}_{33}$, is reported to form through a sluggish reaction between $\mathrm{Na}_{2} \mathrm{Ca}_{3} \mathrm{Al}_{2} \mathrm{~F}_{14}$ and $\mathrm{AlF}_{3}$ [32]. The metastability of $\mathrm{NaCaAlF} 6$ below $600{ }^{\circ} \mathrm{C}$ and the slow-forming reaction of $\mathrm{Na}_{4} \mathrm{Ca}_{4} \mathrm{Al}_{7} \mathrm{~F}_{33}$ most probably explain the appearance of verneite as the only ternary $\mathrm{Na}-\mathrm{Ca}-\mathrm{Al}$ fluoride in fumaroles. 
Table 4. Crystal structure data for the ternary phases from the $\mathrm{NaF}-\mathrm{CaF}_{2}-\mathrm{AlF}_{3}$ system.

\begin{tabular}{|c|c|c|c|c|c|}
\hline Formula & Space Group & $\begin{array}{l}\text { Crystal lattice } \\
\text { Parameters }\end{array}$ & $\begin{array}{l}\text { Structure } \\
\text { Type }\end{array}$ & Aluminofluoride Part & Ref. \\
\hline$\beta-\mathrm{NaCaAlF}_{6}$ & P321 & 8.9295(9), 5.0642(2) ^ & $\mathrm{Na}_{2} \mathrm{SiF}_{6}$ & isolated $\left[\mathrm{AlF}_{6}\right]$ & [20] \\
\hline$\alpha-\mathrm{NaCaAlF}_{6}$ & $\mathrm{P} 2{ }_{1} / \mathrm{c}$ & $\begin{array}{c}\text { 8.7423(3), 5.1927(2), } \\
20.3514(9) \AA, 91.499(2)^{\circ}\end{array}$ & unique & isolated $\left[\mathrm{AlF}_{6}\right]$ & [24] \\
\hline $\mathrm{Na}_{2} \mathrm{Ca}_{3} \mathrm{Al}_{2} \mathrm{~F}_{14}$ & $\mathrm{I} 2{ }_{1} 3$ & $10.257(1) \AA$ & unique & $\begin{array}{l}\text { isolated }\left[\mathrm{AlF}_{6}\right] \text { plus } \\
\text { additional F }\end{array}$ & [13] \\
\hline $\mathrm{Na}_{4} \mathrm{Ca}_{4} \mathrm{Al}_{7} \mathrm{~F}_{33}$ & $\operatorname{Im} 3 \mathrm{~m}$ & $10.781(3) \AA$ & unique & {$\left[\mathrm{Al}_{7} \mathrm{~F}_{33}\right]$ 3D framework } & [20] \\
\hline
\end{tabular}

Author Contributions: Investigation, T.B.-Ž., A.G., D.P. and D.M.; Methodology, T.B.-Ž., A.G., D.P. and D.M.; Software, T.B.-Ž.; Writing—original draft, T.B.-Ž.; Writing—review \& editing, A.G. and D.P.

Funding: This research received no external funding.

Acknowledgments: Authors are indebted to the late S.P. Jakobsson for the collection of the Hekla and Eldfell samples and the initiation of this work, and to E. Leonardsen for the first XRD measurements of verneite. We thank J. Bailey for the correction of the English text and the three anonymous referees for suggestions that improved the manuscript.

Conflicts of Interest: The authors declare no conflict of interest.

\section{References}

1. Jakobsson, S.P.; Leonardsen, E.S.; Balić-Žunić, T.; Jónsson, S.S. Encrustations from three recent volcanic eruptions in Iceland: The 1963-1967 Surtsey, the 1973 Eldfell and the 1991 Hekla eruptions. Fjölrit Náttúrufraedistofnunar 2008, 52, 65.

2. Balić-Žunić, T.; Garavelli, A.; Acquafredda, P.; Leonardsen, E.; Jakobsson, S.P. Eldfellite, $\mathrm{NaFe}\left(\mathrm{SO}_{4}\right)_{2}$, a new fumarolic mineral from Eldfell volcano, Iceland. Mineral. Mag. 2009, 73, 51-57. [CrossRef]

3. Garavelli, A.; Balić-Žunić, T.; Mitolo, D.; Acquafredda, P.; Leonadsen, E.; Jakobsson, S.P. Heklaite, $\mathrm{KNaSiF}_{6}$, a new fumarolic mineral from Hekla volcano, Iceland. Mineral. Mag. 2010, 74, 147-157. [CrossRef]

4. Balić-Žunić, T.; Garavelli, A.; Mitolo, D.; Acquafredda, P.; Leonardsen, E. Jakobssonite, CaAlF 5 , a new mineral from fumaroles at the Eldfell and Hekla volcanoes, Iceland. Mineral. Mag. 2012, 76, 751-760. [CrossRef]

5. Mitolo, D.; Garavelli, A.; Balić-Žunić, T.; Acquafredda, P.; Jakobsson, S.P. Leonardsenite, $\mathrm{MgAlF}_{5}\left(\mathrm{H}_{2} \mathrm{O}\right)_{2}$, a new mineral species from Eldfell volcano, Heimaey Island, Iceland. Can. Mineral. 2013, 51, 377-386. [CrossRef]

6. Jacobsen, M.J.; Balić-Žunić, T.; Mitolo, D.; Katerinopoulou, A.; Garavelli, A.; Jakobsson, S.P. Oskarssonite, $\mathrm{AlF}_{3}$, a new fumarolic mineral from Eldfell volcano, Heimaey, Iceland. Mineral. Mag. 2014, 78, $215-222$. [CrossRef]

7. Balić-Žunić, T.; Garavelli, A.; Mitolo, D. Topsøeite, $\mathrm{FeF}_{3}\left(\mathrm{H}_{2} \mathrm{O}\right)_{3}$, a new fumarolic mineral from the Hekla volcano, Iceland. Eur. J. Mineral. 2018, 30, 841-848. [CrossRef]

8. Balić-Žunić, T. (University of Copenhagen, Copenhagen, Denmark); Jonasson, K. (Icelandic Institute of Natural History, Gardabaer, Iceland). Personal communication, 2013.

9. Ruste, J. X-Ray spectrometry. In Microanalysis and Scanning Electron Microscopy; Maurice, F., Meny, L., Tixier, R., Eds.; Les Editions de Physique: Orsay, France, 1979; pp. 215-267.

10. Acquafredda, P.; Paglionico, A. SEM-EDS microanalyses of microphenocrysts of Mediterranean obsidians: A preliminary approach to source discrimination. Eur. J. Mineral. 2004, 16, 419-429. [CrossRef]

11. Balić Žunić, T.; Vicković, I. IVTON_Program for the Calculation of Geometrical Aspects of Crystal Structures and Some Crystal Chemical Applications. J. Appl. Cryst. 1996, 29, 305-306. [CrossRef]

12. Mandarino, J.A. The Gladstone-Dale relationship. I. Derivation of new constants. Can. Mineral. 1976, 14, 498-502.

13. Courbion, G.; Ferrey, G. $\mathrm{Na}_{2} \mathrm{Ca}_{3} \mathrm{Al}_{2} \mathrm{~F}_{14}$ : A new example of a structure with "independent $\mathrm{F}^{- \text {" }-\mathrm{A} \text { new }}$ method of comparison between fluorides and oxides of different formula. J. Solid State Chem. 1988, 76, 426-431. [CrossRef]

14. Effenberger, H.; Kluger, F. Ralstonit: Ein Beitrag zur Kenntnis von Zusammensetzung und Kristallstruktur. N. Jahrb. Miner. Monat. 1984, 1984, 97-108. 
15. Sawada, H. An electron density residual study of alpha-ferric oxide. Mater. Res. Bull. 1996, 31, 141-146. [CrossRef]

16. Balić Žunić, T.; Makovicky, E. Determination of the centroid or "the best centre" of a coordination polyhedron. Acta Cryst. 1996, B52, 78-81. [CrossRef]

17. Makovicky, E.; Balić-Žunić, T. New measure of distortion for coordination polyhedra. Acta Cryst. 1998, B54, 766-773. [CrossRef]

18. Balić-Žunić, T. Use of three-dimensional parameters in the analysis of crystal structures under compression. In Pressure-Induced Phase Transitions; Grzechnik, A., Ed.; Transworld Research Network: Kerala, India, 2007; pp. 157-184, ISBN 81-7895-272-6.

19. Bolotina, N.B.; Maximov, B.A.; Simonov, V.I.; Derzhavin, S.I.; Uvarova, T.V.; Apollonov, V.V. Crystal structure and spectral characteristics of $\mathrm{LiCaAlF}_{6}: \mathrm{Cr}^{3+}$ single crystals. Crystallogr. Rep. 1993, 38, 446-450.

20. Hemon, A.; Courbion, G. The NaF-CaF $2-\mathrm{AlF}_{3}$ system: Structures of beta-NaCaAlF 6 and $\mathrm{Na}_{4} \mathrm{Ca}_{4} \mathrm{Al}_{7} \mathrm{~F}_{33}$. J. Solid State Chem. 1990, 84, 153-164. [CrossRef]

21. Hemon, A.; Le Bail, A.; Courbion, G. Crystal structure approach of $\mathrm{KCaAl}_{2} \mathrm{~F}_{9}$. A new hexagonal tungsten-bronze related structure. Eur. J. Solid State Inor. Chem. 1993, 30, 415-426. [CrossRef]

22. Hemon, A.; Courbion, G. Refinement of the room-temperature structure of alpha-CaAlF 5 . Acta Cryst. C 1991, 47, 1302-1303. [CrossRef]

23. Domesle, R.; Hoppe, R. The crystal structure of $\mathrm{Ca}_{2} \mathrm{AlF}_{7}$. Z. Kristallogr. 1980, 153, 317-328. [CrossRef]

24. Le Bail, A.; Hemon-Ribaud, A.; Courbion, G. Structure of alpha-(Na Ca Al F6) determined ab initio from conventional powder diffraction data. Eur. J. Solid State Inor. Chem. 1998, 35, 265-272. [CrossRef]

25. Werner, F.; Weil, M. Alpha-(BaCaAlF 7$)$. Acta Cryst. E 2003, 59, 17-19. [CrossRef]

26. Litvin, A.L.; Petrunina, A.A.; Ostapenko, S.S.; Povarennykh, A.S. The crystal structure of usovite. Dopov. Akad. Nauk Ukr. RSR Ser. B 1980, 3, 47-80. (In Ukrainian)

27. Kampf, A.R.; Yang, H.; Downs, R.T.; Pinch, W.W. The crystal structures and Raman spectra of aravaipaite and calcioaravaipaite. Am. Mineral. 2011, 96, 402-407. [CrossRef]

28. Mumme, W.G.; Grey, I.E.; Birch, W.D.; Pring, A.; Bougerol, C.; Wilson, N.C. Coulsellite, $\mathrm{CaNa}_{3} \mathrm{AlMg}_{3} \mathrm{~F}_{14}$, a rhombohedral pyrochlore with 1:3 ordering in both A and B sites, from the Cleveland mine, Tasmania, Australia. Am. Mineral. 2010, 95, 736-740. [CrossRef]

29. Swanson, H.E.; Tatge, E. Standard X-ray diffraction powder patterns. Nat. Bur. Stand. Circ. 1953, 539, 69-70.

30. Bevan, D.J.M.; Straehle, J.; Greis, O. The crystal structure of tveitite, an ordered yttrofluorite mineral. J. Solid State Chem. 1982, 44, 75-81. [CrossRef]

31. The American Mineralogist Crystal Structure Database. Available online: http://rruff.geo.arizona.edu/ AMS/amcsd.php (accessed on 28 November 2018).

32. Craig, D.F.; Brown, J.J. Phase equilibria in the system $\mathrm{CaF}_{2}-\mathrm{AlF}_{3}-\mathrm{Na}_{3} \mathrm{AlF}_{6}$ and part of the system $\mathrm{CaF}_{2}-\mathrm{AlF}_{3}-\mathrm{Na}_{3} \mathrm{AlF}_{6}-\mathrm{Al}_{2} \mathrm{O}_{3}$. J. Am. Ceram. Soc. 1977, 63, 254-261. [CrossRef]

(C) 2018 by the authors. Licensee MDPI, Basel, Switzerland. This article is an open access article distributed under the terms and conditions of the Creative Commons Attribution (CC BY) license (http://creativecommons.org/licenses/by/4.0/). 